\title{
Loyalty to the Cultural Homeland (196o-1965): Critical Ethnocentrism as an Anticipatory Defense against Relativism and Interpretative Anthropology
}

\author{
A Critic of Interpretative Anthropology Ante Litteram: \\ The Anthropologist of Guilt Becomes a Philosopher of the \\ Apocalypse of Relativism
}

During the final years of his life, de Martino's bibliography boasts a variety of different writings, such as a collection of theoretical articles published as Fury, Symbol, Value (1962), interventions on the epic biography of Sigmund Freud by Ernest Jones, an article overviewing the history of anthropology, or an anthology of texts provocatively entitled Magic and Civilization (1962). This being said, there was one topic that dominated de Martino's final life-stage, namely the apocalypse. ${ }^{1}$ While certain interests-particularly the Judeo-Christian conceptions of time, the repetition of mythic contents, moments of crisis and recovery in primitive cultures, or the phenomenology of psychopathological conditions - appear to correlate to virtually every earlier stage of his career, his fascination with the apocalypse in modernity is also a direct result of the historical context in which de Martino found himself during the 196os. Indeed, like many of his contemporaries, de Martino was acutely aware of the division of the world into two hegemonic blocks during the Cold War and the accompanying terror of the atomic threat. ${ }^{2}$ In "The Problem of the End of the World," a conference presentation held the year before his death, he explained:

It is anything but improbable that the modern age's acute cultural consciousness of the ending of the world has also drawn nourishment from the possibility of the nuclear war or from the terrifying episodes of

1 Ernesto De Martino, Furore simbolo valore (Milano: Il saggiatore, 1962); De Martino, Magia e civiltà; Ernesto De Martino, "Etnologia e storiografia religiosa nell'opera di Freud," Homo 4, no. 1 (January 1963): 47-50; De Martino, "Etnologia e civiltà moderna."

2 Clara Gallini, "Introduzione," in La fine de mondo, by Ernesto De Martino (Torino: Einaudi, 1977), xlii; Cherchi, Il signore del limite. Tre variazioni critiche su Ernesto de Martino, 3-4; Giovanni Jervis, "Psicopatologia e apocalissi," in Dell'apocalisse. Antropologia e psicopatologia in Ernesto de Martino, ed. Bruna Baldacconi and Pierangela Di Lucchio (Napoli: Guida, 2005), 51 . 
genocide in the Nazi death camps. But already the fact that we needed the two hundred thousand of Hiroshima or the six million Jews that perished in the extermination camps indicates to us how deep the roots of our crisis are. As a matter of fact, the image of just a single human face that carries the signs of violence and injury suffered on the hands of another human being should suffice to set in motion [...] the dramatic tension of the world that can but should not end. [...] There are other aspects of the modern world that have rendered our sensibility for the risk of the end more acute. The very fast transformations in lifestyles introduced by the diffusion of technical progress, the migratori currents from the countryside to the city, from underdeveloped to industrial regions, the sudden leap from more or less rudimentary economies or even tribal societies to economies and societies already integrated in the Western world have all led to the crisis of a great number of traditional cultural homelands. The rapid processes of transition, the lacerations and the voids that they entail, the loss of cultural models in a situation that can no longer use the familiar ones, bring about considerable crises and, in the most dramatic mode, propose anew the elementary problems of the relationship with the world. ${ }^{3}$

Staying true to the topos of the earthquake, de Martino collected a series of accounts from psychopathology that depict catastrophic visions, describing experiences of the "wholly other of the solid ground on which one walks: 'the ground that fails (manca) under the feet,' the earthquake, the collapsing of the ground." ${ }^{4}$ In one passage, he discussed the case of a farmer from Bern, whose apocalyptic visions were protocolled by two German psychiatrists in 1950. In this account of the "apocalyptic delirium," de Martino noted that the Swiss patient "perceives the abyssal character of his world like an 'earthquake." In another passage, de Martino cited a similar account, this time protocolled by the psychiatrist Albrecht Wetzel:

Darkness, stiffness, immobility, inertia, collapsing of the ground, earthquake: I thought an earthquake was about to happen. I read in the bible that there is division on earth and so I thought that God would have

3 Ernesto De Martino, "Il problema della fine del mondo," in Il Mondo di domani, ed. Pietro Prini (Roma: Edizioni Abete, 1964), 227.

4 De Martino, La fine del mondo, 84.

5 De Martino, 201. For the original account, see Alfred Storch and Caspar Kulenkampff, "Zum Verständnis Des Weltuntergangs Bei Den Schizophrenen," Der Nervenarzt 21, no. 3 (1950): $102-8$. 
come down to earth to give them only one confession. I saw that it was dark, there was no cloud, and then everything was so calm, immobile, the leaves hung inert. Then, when they moved, I thought there was an earthquake somewhere ... I did not hear the earthquake. Already a few days earlier I had told my husband that an earthquake was going to happen. ${ }^{6}$

In this depiction, we not only witness the importance of the earthquake as a means to express the fear of the apocalypse, but also the close association between the trembling of the earth and the religious, particularly Christian narratives surrounding the end. De Martino himself, repeatedly mentioned the Christian accounts of the events leading up to the end of the world, paying particular attention to Matthew 24,1-8, where earthquakes are named as one of the most important signs of the coming of apocalyptic times. ${ }^{7}$ For de Martino, in fact, the material dimensions of the apocalypse were only a superficial epiphenomenon of a much deeper civilizational crisis. Dedicating the final years of his life to reflections of a moral and philosophical nature of the end of the world, de Martino believed that the socio-political upheavals of his age "evoke a much more secrete, profound, and invisible catastrophe," of which the "mushroom cloud of Hiroshima" is only the "real image,".

The expression "crisis of traditional homelands" points to the true nature of this intellectual nature of the apocalypse, which is nothing else than a naked catastrophe of everything that is worldly, homely, and familiar. In the posthumously published notes of The End of the World (1977), de Martino speaks to the future generation about an apocalypse without eschaton and explained that it should be understood as the threat of disintegration of our cultural universe, of our system of socially and inter-subjectively shared values, which shapes our collective actions. In the crisis affecting their culture during the 1960s-and well into the following decades-Western intellectuals had lost the ability to transform the universe into a world that they could domesticate and populate with their own horizons of meaning. The most radical expression of this loss of meaning, so de Martino believed, was twofold and corresponded to the cultural-discursive paradigm: The crisis was cultural and found

6 De Martino, La fine del mondo, 35. For the original account, see Albrecht Wetzel, "Das weltuntergangserlebnis in der schizophrenie," Zeitschrift für die gesamte Neurologie und Psychiatrie 78, no. 1 (1922): 403-28.

7 De Martino, La fine del mondo, 336, 343. In another instance, he also cites Apocalypse, 6, 12-17, where the accounts starts with a great earthquake. He also references Matthew 27, $5^{1}$ and Luke 23,45 , noting that they recount the time when Jesus was crucified as a moment when the earth was shaking. See, De Martino, 319, 338.

8 De Martino, La fine del mondo, 470. 
its expression in cultural relativism (the subject of this chapter), and it was discursive and manifested in postmodernism's symbolization of reality (to be discussed in chapter 6).

Regarding the cultural and the discursive turns, de Martino offered both an analysis of the movement, pointing to their inherent risks, as well as an anticipatory answer to the crises they provoked. I am aware of the fact that I commit the sin of engaging in an anachronistic reading of de Martino's work that does not correspond to the principle of historical contextualization that marked the first chapters of this book. However, I felt it worth-while to speak of de Martino's relationship to relativism and postmodernism - even if only ante litteram - for two reasons: First, because he can offer us resources to understand and counteract certain intellectual trends that persist in contemporary academia. Second, because existing scholarship on de Martino celebrated him as a harbinger of postmodernism, thus warranting a more thorough discussion of his role within this trend.

In highlighting de Martino's critical stance towards the cultural-discursive paradigm, I decisively contradict Fabrizio Ferrari's statement that “de Martino's theories anticipated [...] post-modern discourses." 9 In this first introduction to de Martino's life for anglophone readership, an otherwise commendable effort, Ferrari uses the terms "post-modern" and "post-modernism," "post-structural" and "post-structuralism," and "post-colonial" and "post-colonialism" well over fifty times. In support of his line of reasoning, he cites expressions of these currents from a long list of illustrious figures: Derrida, Ricoeur, Levinas, Sartre, Geertz, Crapanzano, Taussig, Rosaldo, Clifford, Marcus, Said, Bhabha, and Spivak. ${ }^{10}$ Of course, as I have shown in the previous chapter, Ferrari is right in

Fabrizio M. Ferrari, Ernesto De Martino on Religion, 105. While Ferrari cites Berrocal and Saunders repeatedly throughout his study (even using their translations of de Martino's texts), he seems unaware of the postmodern receptions of Hauschild, Lanternari, or Dei and Simonicca. Ferrari's claims are also significantly stronger and more definite than those of his predecessors. While Dei and Simonicca speak of a "prefiguration" and Saunders explicitly notes that de Martino should not be seen as a postmodern ante litteram, Ferrari reverses this tendency by speaking specifically of "his postmodernism ante litteram." Fabio Dei and Alessandro Simonicca, "Il fittizio lume della magia': su de Martino e il relativismo antropologico," in Ernesto de Martino nella cultura europea, ed. Clara Gallini and Marcello Massenzio (Napoli: Liguori, 1997), 271; Saunders, "Un appuntamento mancato: Ernesto de Martino e l'antropologia statunitense," 57; Fabrizio M. Ferrari, Ernesto De Martino on Religion, viii.

10 Note the similarity of this list with the one produced by James Clifford in his Writing Culture, where he lists Emmanual Le Roy Ladurie, Natalie Davis, Carlo Ginzburg, Stephen Greenblatt, Hayden White, Edward Said, Fredric Jameson, Pierre Bourdieu, Michel de Certeau, Raymond Williams, Tzvetan Todorov, and Louis Marin. James Clifford, 
arguing that de Martino's thought anticipated ideas developed by these thinkers. On the whole, his science was one without clearly defined foundations, essences, or universals that defined much of his age. His thinking was deconstructive and open-ended. He participated in a global attempt to move beyond the dualisms that have defined the modern age and one could even argue that his thinking is dialogical, moving in the realm of thirds, rather than according to a binary logic. Finally, like many of the cultural-discursive paradigm's greats listed by Ferrari, he was acutely attuned to the shifting boundaries between secularization and political religion, science and religion, emic and etic approaches to religious phenomena, and so forth. This being said, as I will show, de Martino was not simply anticipating the postmodern, postcolonial, and post-structural thinkers, but also formulated a critical analysis of their premises and an anticipatory response to them.

\section{Moving with and beyond Antonio Gramsci: From Progressive Folklore to a More Successful Colonialization}

Before engaging in the intellectual afterlife of de Martino, however, it might be useful to look at another Italian thinker, whose work has been associated with postcolonial theory, namely Antonio Gramsci (1891-1937). Indeed, it seems clear that Gramsci played an important role in de Martino's development as an anthropologist and thinker of the South. If I have already shown how de Martino critiqued the divided nature of his discipline by critically engaging the international study of religion and magic, it is important to note that he also lamented the presence of a similar division in the treatment of the Italian South. In their attitudes, Marxists and Populists - the two camps engaged in the Southern Question - reflected what George Saunders called the dual function of "the alien" as something that "attracts and repels simultaneously."11 De Martino himself caricatures the two attitudes as follows:

On the one hand, these traditions are considered as simple relicts of a mediocre past, as a document of the backwardness of the Southern plebs, as a medley of oddities and superstitions that one hopes disappear as

"Introduction: Partial Truths," in Writing Culture: The Poetics and Politics of Ethnography, ed. James Clifford and George E. Marcus (Berkeley: University of California Press, 1986), 3.

11 George R. Saunders, "The Magic of the South: Popular Religion and Elite Catholicism in Italian Ethnology," in Italy's "Southern Question": Orientalism in One Country, ed. Jane Schneider (Oxford: Berg, 1998), 178. 
quickly as possible; on the other hand, one idolizes the cheerful and noisy splendor of the popular celebrations of the South, the archaic customs of Lucania and Sardinia, the charm of the songs from Gallura or from Lugodoro, and one almost regrets that this world is about to die out. ${ }^{12}$

Unlike de Martino's work, Gramsci's treatment of what Timothy Brennan calls "Southernism"13 has received ample attention across the globe. There is no doubt that Antonio Gramsci fought the same battles as his much less famous colleague. On the one hand, although he has been called "the patron saint of the Italian Communist party,"14 Antonio Gramsci relentlessly stood up for a more self-consciously critical orientation of Italian Marxism. Like de Martino, Gramsci spent much of his time "combating the dogmatic economism" of his Italian comrades..$^{15}$ On the other hand, in articles such as "Observations on Folklore" (1950), Gramsci was leery of any folkloric, picturesque, and romantic conception of the mezzogiorno, arguing that "however isolated and seemingly remote such communities may appear, they are in fact embedded in larger political and economic realities."16

Antonio Gramsci was born in 1891 on the island of Sardinia and lived through an exceptionally difficult childhood marked by marginalization due to familial neglect, economic poverty, and a particular physical deformity that made him hunch-backed. Despite leaving school at age eleven to support his family, he ended up studying at the University of Turin, where the bright and passionate youth found himself in an entirely different cultural context than in his native region. In what was then Italy's industrial capital, Gramsci benefitted not only from a thriving university, but also entered into contact with a self-conscious, organized, and combative working class. ${ }^{17}$ Once the Italian Socialist Party split in January 1921 at Livorno, Gramsci was quick to establish himself as one of the leaders of the newly formed Italian Communist Party (PCI, Partito Comunista Italiano). Spending two years in Moscow, representing the party, he returned

12 Ernesto De Martino, "Amore e morte," Meridione 9, no. 1-2 (1956): 77.

13 Timothy Brennan, "Antonio Gramsci and Postcolonial Theory: 'Southernism," Diaspora: A Journal of Transnational Studies 10, no. 2 (2001): 143-87, https://doi.org/10.1353/ dsp.2011.0004.

14 Hughes, Consciousness and Society, 99.

15 Hughes, 102; Kate Crehan, Gramsci, Culture and Anthropology (Berkeley: University of California Press, 2002), 22, 72, 89.

16 Crehan, Gramsci, Culture and Anthropology, 5, 99; Carles Feixa, "Más allá de Éboli: Gramsci, de Martino y el debate sobre la cultura subalterna en Italia," in El folclore progresivo y otros ensayos, by Ernesto De Martino, ed. Carles Feixa (Barcelona: Universitat Autònoma de Barcelona, 2009), 18-19; Signorelli, Ernesto de Martino, 19.

Wohl, The Generation of 1914, 192. 
to an Italy ruled by Mussolini and lived a clandestine existence before being arrested and sentenced to twenty years in prison in 1926. Released in 1934 due to ill health, he died three days later, at age forty-six.

Like de Martino, Gramsci has been described as the epitome of the "crisisborn hero," whose work was driven by the aspiration to transform a broken society. ${ }^{18}$ While this activist orientation, the integration of action and theory was a hallmark of Marxist philosophy since its inception in the works of Marx and Engels, there is no doubt that these two attributes coalesced in Antonio Gramsci's opus more than in any other Marxist before him. ${ }^{19}$ Kate Crehan, in one of the most stimulating studies on the Sardinian thinker, has noted that Gramsci's "analytical starting point was very different from that of academic anthropology" as he was "first and foremost a political activist whose primary concern was to bring about political change in Italy." ${ }^{20}$ Gramsci used the term "organic intellectual" (intellettuale organico) to describe the ideal thinker, who is able to integrate political activism aimed at the practical transformation the world with intellectual engagement intent on generating knowledge. ${ }^{21}$ Perhaps the greatest energy de Martino drew from Gramsci's work as an organic intellectual geared towards transforming culture, is the latter's insistence on the need to enable the Southern peasants to become historical actors of their own destiny, to remedy their poverty and misery, and to contribute to the unification of Italy. Gramsci believed that all previous movements of unification, including the Risorgimento led by Giuseppe Mazzini had failed to overcome the division in the Italian nation. ${ }^{22}$ De Martino himself called for the "unification of the national culture as Gramsci conceived it," and defined the process as "the formation of a new cultural life of the nation that heals the fracture between high culture and the culture of the people."23

De Martino's attempts at unification can be divided into different expressions, which evolved throughout this period and ultimately led him beyond both Gramsci and the Southern Question. In a first phase during the late 1940s,

18 See, for example, Mihály Csíkszentmihályi, Flow: The Psychology of Optimal Experience. (New York: Harper \& Row, 1990), 234.

19 Joachim Ranke, Marxismus und Historismus bei Antonio Gramsci: philosophische und sozialwissenschaftliche Untersuchungen (Frankfurt am Main: P. Lang, 1989); Crehan, Gramsci, Culture and Anthropology.

20 Crehan, Gramsci, Culture and Anthropology, 5.

21 Hughes, Consciousness and Society, 102-3; Saunders, "The Magic of the South," 188; Crehan, Gramsci, Culture and Anthropology, 128-64; Mancini, "Postface," 288-89.

22 Wohl, The Generation of 1914, 195.

23 Ernesto De Martino, "Il folklore progressivo," in Antropologia culturale e questione meridionale: Ernesto de Martino e il dibattito sul mondo popolare subalterno negli anni 1948-1955, ed. Carla Pasquinelli (1951; repr., Firenze: La Nuova Italia, 1977), 145. 
he simply tried to augment the Marxist focus on the economic circumstances by complementing it with an increased attention to the real needs of the people. In "The Civilization of the Spirit" (1948), for example, he described the case of a day laborer from the town of Minervino, who expressed anguish in light of his weakening strength, his inability to work and provide, and his fears of becoming a burden to his family. ${ }^{24}$ In his reflections on the peasant's experience, de Martino not only converted these anxieties into an existential fear of losing any type of spiritual value and human dignity in light of an "image [...] of life and world [...] as oppressive dependence on 'matter," but he also called for a "real, revolutionary liberation of man from the servile moment of inevitable materialistic dependence." 25

In the same vein, his "Lucanian Notes" (1950) considered the case of another day-laborer by the name of Rocco Tammone. After introducing his dire economic situation with a "naked list of numbers" - precisely outlining his hours of work, the size of the land he was working, the harvest of grain and wine, and the amounts of money he owes to different people in town-de Martino then proceeded to describe him as a "man full of humanity." ${ }^{26} \mathrm{He}$ reproduced a letter that Tammone sent to Rocco Scotellaro, the Socialist mayor of his hometown, in which he tells the story of a tragic accident of a four-year old child of his own family. ${ }^{27}$ In his conclusion, de Martino comments:

The humanity of Rocco Tammone poses the general question of the humanity and of the "civilization" of the people of Tricario. As much as the use of the word "civilization" in referring to the material conditions of existence of these people could sound atrociously derisive, it is a fact, that even such conditions nourish experiences and affection, customs and ideologies, which shape civilization and history. There is a basic form

24 Ernesto De Martino, "La civiltà dello spirito," in Scritti minori su religione marxismo e psicoanalisi, ed. Roberto Altamura and Patrizia Ferretti (1948; repr., Roma: Nuove edizioni romane, 1993), 115 .

25 De Martino, 116-17.

26 De Martino, "Note lucane," 653.

27 De Martino, 652. Son of a farming family of Tricarico, a large village in the province of Matera, Scotellaro attended the liceo in the North of Italy only to return to Basilicata in his early twenties to emerge as one of the most important writers, researchers, and political activists of the mezzogiorno. Both of them being members in the Italian Socialist Party, Ernesto knew Rocco personally and the young man - who had become mayor of Tricarico by that time-invited him and Vittoria several times between 1949 and 1952 to stay in his family's home. The literary production of the peasant poet, published only after his early death in 1953, has not only been compared to that of his most influential mentor, Carlo Levi, but also to neorealism. 
of experience from which the people of Tricarico has to continuously defend itself in order to save its proper humanity, in order to ward off the savage temptation of things, without prospect, sordid, and deformed. In these houses, with this life, it is very difficult to preserve oneself as human, to at least sustain a weak shimmering of this complex of love and relationships that characterizes humanity. ${ }^{28}$

In this immensely influential article, de Martino also hints at his second strategy that could lead to the unification of Italy, namely "progressive folklore" (folklore progressivo). In this second stage, which is concomitant to his increased ethnographic expeditions and his new identity as a "militant ethnographer" starting around 1950, he argued that the portrayal of Southern reality in un-romanticized ways was no longer enough for unifying the country. Instead of images of the poor produced by the elite, de Martino focused on the revolutionary potential of the subaltern masses itself. In one of his oeuvre's most impactful passages, we read "men and women came out of their filthy hideouts and asked me to tell and to narrate, to render the history of their hardship and their trembling rebellion public." 29 The following year, in an article entitled "Progressive Folklore," de Martino noted that "if we want this to be a concrete and real unification, it also has to involve the admission of that progressive popular production to the cultural circle, which $[. .$.$] ties itself to the$ process of political and social emancipation of the people themselves." ${ }^{30} \mathrm{He}$ defines "progressive folklore" as the "informed proposal of the people against their own socially subaltern condition" and as a position that "comments and expresses the struggles to emancipate from it in cultural terms." ${ }^{31}$

In a talk at the conference organized by the Gramsci Foundation (Fondazione Gramsci) to present the publication of the Fourth Volume of Gramsci's Prison Notebooks, de Martino lauded "the multiplication of progressive elements in folklore itself, that is to say cultural elements that are born as protest by the people against their own subaltern condition, or that culturally comment and express the struggles to emancipate themselves from it." ${ }^{32} \mathrm{He}$ explained that he sees this combative force in various newly emergent traits of the Southern culture, such as the Resistance, the occupation of lands and factories, strikes

\footnotetext{
28 De Martino, 654.

29 De Martino, 66o.

$30 \quad$ De Martino, "Il folklore progressivo," 145.

31 De Martino, 144.

32 Ernesto De Martino, "Gramsci e il folklore," in Antropologia culturale e questione meridionale: Ernesto de Martino e il dibattito sul mondo popolare subalterno negli anni 1948-1955, ed. Carla Pasquinelli (Firenze: La Nuova Italia, 1977), 156-57.
} 
and political celebrations. ${ }^{33}$ De Martino became particularly fascinated with one form of progressive folklore, namely popular songs. In another article from this period, he invited all his readers to send him any progressive popular songs, and elaborated their nature as follows:

There exists today in Italy a whole prominent patrimony, a genuine solemn singing comment, which accompanies the laborer and peasant movement in its history. These are songs that sometimes express simple protest, other times open rebellion against the subaltern condition to which the people are condemned. These are satirical folk songs against the enemy of class, epic memories of ancient and recent struggles, lyric derelictions to passionate anticipation of the better world of tomorrow. [...] It is up to us to assemble this heritage, to conserve it, to put it back into circulation, and, most of all, to stimulate its increase: this is an aspect of the new humanism underway that cannot be neglected. ${ }^{34}$

Progressive folklore reveals an ambiguous dimension in de Martino's relationship with Gramsci. While every article he wrote about progressive folklore references his name, Gramsci appears to be serving primarily as a shadow, which allowed de Martino to define his own contours. ${ }^{35}$ Passages that would actually support his argument are conspicuously absent in his treatises. Consider, for instance, the curious fact that de Martino completely ignored the previously mentioned "Observations on Folklore." Here, Gramsci distinguished between "various strata" of Southern culture, "the fossilized ones which reflect conditions of past life and are therefore conservative and reactionary, and those which consist of a series of innovations, often creative and progressive, determined spontaneously by forms and conditions of life which are in the process of developing and which are in contradiction to or simply different from the morality of the governing strata." 36 The reason for this neglect might lie in the fact that in Gramsci, the potential for progress that grows out of the oppositional

33 De Martino, ${ }^{156-57}$.

34 Ernesto De Martino, "Il folklore," in Antropologia culturale e questione meridionale: Ernesto de Martino e il dibattito sul mondo popolare subalterno negli anni 1948-1955, ed. Carla Pasquinelli (Firenze: La Nuova Italia, 1977), 147.

35 For attempts to explain this strategy, see Angelini, Ernesto de Martino, 68-69; Pasquinelli, "Introduzione," 26.

36 Antonio Gramsci, Letteratura e vita nazionale. (Torino: Einaudi, 1950), 216-17; Antonio Gramsci, Selections from Cultural Writings, ed. David Forgacs and Geoffrey Nowell-Smith (Cambridge: Harvard University Press, 1985), 19o. See also, Crehan, Gramsci, Culture and Anthropology, 108. 
nature of subaltern culture is immediately relativized by his overall negative conception of Southern society, which is described as an implicit, incoherent, contradictory, and disintegrated worldview. ${ }^{37}$ In her discussion of Gramsci's attitude, Jane Schneider rightly detects a "pessimism about the capacity of Southern peasants to act in history."38

De Martino himself would ultimately transcend Gramsci, particularly in the second half of the decade, which would culminate in the books of the Southern Trilogy, published between $195^{8}$ and 1961. It is at this moment that de Martino's project of unification of Italy gradually lost its militant and political undertones to become philosophical project concerned with the destiny of (post)-modern Western society. If the shifting boundaries between hegemonic and subaltern cultures remained a propelling energy, its nature is now explored in another way: The encounter with the uncivilized South becomes less a problem of the South, and more a problem of the limited civilizational power of the North - what Alessandro Testa called a "sort of unsuccessful colonialization."39

In the final years of the 1950s, the dying down of political activism, the gradual improvement of his health, and tentative indications of professional recognition in academia went hand in hand to transform de Martino's life radically. Although it is not clear whether he actively left the party or just chose not to renew his membership in 1957, there is no doubt that his socialist political ambitions took a severe blow as a consequence of two events demonstrating the culturally intolerant and authoritarian nature of socialist regimes. ${ }^{40}$ Within a few months in 1956, the Poznań Uprising in Poland and the Hungarian Revolution against Stalinism posed the greatest threat to the Soviet control of these territories since wWII, leading to violent suppressions that ended up costing the lives of thousands and the displacement of hundreds of thousands. The same incidents in the East also reconfirmed his growing isolation within Marxist circles and his rising disappointment about the failure of Italian communism to truly emancipate the subaltern masses. ${ }^{41}$

37 Gramsci, Letteratura e vita nazionale., 215; Gramsci, Selections from Cultural Writings, 189.

38 Jane Schneider, "Introduction: The Dynamics of Neo-Orientalism in Italy (1848-1995)," in Italy's “Southern Question”: Orientalism in One Country, ed. Jane Schneider (Oxford: Berg, 1998), 14.

39 Testa, "Estasi e crisi. Note su sciamanismo e pessimismo storico in Eliade, de Martino e Lévi-Strauss," 108.

40 Patrizia Ferretti, "Nota biobibliografica," in Scritti minori su religione marxismo e psicoanalisi, ed. Roberto Altamura and Patrizia Ferretti (Roma: Nuove edizioni romane, 1993), 162-63; Gallini, "Introduzione," LXXV-LXXvI; Angelini, Ernesto de Martino, 154. Gallini, "Introduzione." 
As he gradually distanced himself from Gramsci and from militant ethnography, de Martino made his first steps in the university system by becoming a lecturer (libero docente) in anthropology (1953-1955) and history of religions $(1956-1958)$ at the Sapienza University in Rome. In the last years of his life, he finally received some much-deserved recognition from his contemporaries. In 1958, he published Death and Ritual Weeping, winning the prestigious Viareggio Literature Prize precisely eleven years after it was awarded to none other than Gramsci for his Prison Notebooks. A year later, he achieved another milestone in his career as he was appointed as full professor (professore straordinario) of religious studies; not in Rome, where his friend Angelo Brelich inherited the position of Raffaele Pettazzoni, but at the University of Cagliari on Sardinia.

Before leaving for the island in the summer of 1959, de Martino and his interdisciplinary team of researchers undertook one last expedition in the Italian South, where they documented the case of the tarantate, women possessed by the spirits of spiders whose richest ritualistic expression takes place during the yearly celebration of St. Paul on the 28th and 29th of June. The results of the research on tarantism in the small town of Galatina, in the heart of Salento, was handed over to Mondadori publisher the following year and published as The Land of Remorse in 1961. With that project, de Martino finally closed his Southern Period for good. Arrived at the zenith of his fame in Italy-endowed with a permanent position as the chair in religious studies at Cagliari-the foremost anthropologist of the Italian South added another remarkable twist to his intellectual itinerary. Abandoning the research of folklore, he decided to dedicate his new life to old passions centered on the destiny of Western civilization, once again articulated in between decline and rebirth. As he himself put it, he returned to research "born in the arena of contemporary history," circumscribing it as the "cognitive clarification of operative nodes in which our own age is caught up." 42

\section{Nostalgia for the Lost Homeland: An Anticipatory Analysis of the Cultural Turn and the Surprising Parallels between Cultural Relativism and the Insider-Phenomenological Approach}

While I will not engage every thinker on Ferrari's list mentioned above, even a short glance at the priorities of the main protagonists of the shift in the intellectual climate during the cultural and linguistic turns makes it clear why historians of the discipline of religious studies tend to emphasize that the 
insider-phenomenological current was replaced as the cultural-discursive paradigm came to the fore. Michael Stausberg, for example, maintains that "the 1970s marked the twilight of the phenomenology of religion, the rejection of which has now become the standard prologue to contemporary attempts at self-understanding within the field." ${ }^{33}$ Gavin Flood, similarly, noted a "shift of emphasis from a philosophy of consciousness to a philosophy of the sign, from consciousness to language, culture and intersubjectivity around the same time." ${ }^{44}$ Of course, my own account in chapter 5 , in which I noted that the ontological paradigm was gradually superseded by the cultural-discursive model of thought, has certainly lent some credibility to this account. This, however, is far from the whole story. De Martino rightly intuited that the insiderphenomenological approach received a surprising afterlife in the emergent third model for the study of religion. The key to understanding the continuity between these two seemingly different currents of thought lies in their shared cultural relativism, which is driven by a nostalgia for cultural alterity.

From a historical point of view, so much is well-known, the continuous presence of relativism makes sense as American interpretative anthropology was ultimately nourished through the umbilical cord of a German matrix. Specifically, the concept of culture, in the American context, was primarily shaped by Franz Boas (1858-1942), who emigrated from Germany to New York at the age of twenty-nine. After growing up in Westphalia, Boas studied geography, which led him to a one-year fieldwork stay on Baffin Island (1883-1884). It was during this year of research amongst the indigenous Eskimo population that Boas stood up against the geographical determinism of his teacher Friedrich Ratzel and started to promote his appreciation of cultural phenomena as autonomous of geographic, racial, or biological conditioning. After returning to Germany, where he worked at the Royal Ethnological Museum in Berlin and attained his habilitation with Adolf Bastian in 1896, Boas settled in the United States to work at Columbia University and at the American Museum of Natural History.

In the first decades of the twentieth century, Boas and his disciples collectively changed the face of American anthropology, leading it gradually from evolutionism to cultural relativism. Although the students of Boas were anything but a coherent and unified group, they all propagated their teacher's conception of culture as a bounded whole. ${ }^{45}$ As one commentator put it, "the

43 Stausberg, "Western Europe," 32.

44 Flood, Beyond Phenomenology, 117.

45 Stocking includes Lowie, Leslie Spier, Herskovits, Wissler, Speck, Kroeber, Sapir, Radin, Benedict, and Mead in the list of Boasians. George Ward Stocking, "Introduction: The 
Boasian paradigm, elaborated and reshaped by his students over three generations, dominated American anthropology until mid-century."46 Particularly, Ruth Benedict's Patterns of Culture (1934) has exerted a tremendous influence on American anthropology, continuing to promote values of cultural relativism through its attempts to achieve a "deep penetration into the genius of the culture." 47

The Boasian model persisted even into the final decades of the twentieth century. In fact, one of the most vital offshoots sprouting from the fertile ground of Boasian anthropology was Clifford Geertz (1926-2006). Born in California, serving in the U.S. Navy in wwII, and graduating from Harvard in Social Anthropology, the formative events in Geertz's career were the personal encounters with cultural alterity through his fieldwork on the Indonesian islands of Java and Bali, and in Morocco. Appointed as professor at the University of Chicago in 196o, he would become the first social scientist appointed at the prestigious think tank known as the Institute for Advanced Study at Princeton ten years later. Throughout this period, he gradually moved towards what has been described as "extreme culturalist positions,"48 which would ultimately culminate in the publication of the foundational book of the cultural turn, namely The Interpretation of Culture (1973).

A rather banal but nonetheless powerful indication for Geertz's underlying affinity with Boasian thinking about culture, comes from the title of his paradigm-shifting book. Indeed, by using the plural grammatical form, Geertz indicates that he, like Boas before him, was not searching for culture as a universal concept but rather cultures as particular and unique constructs. In "Religion as a Cultural System," which was published as part of his magnum opus, he famously defined culture as having "neither multiple referents, nor, so far as I can see, any unusual ambiguity." Instead, so he specified, "it denotes an historically transmitted pattern of meanings embodied in symbols, a system of inherited conceptions expressed in symbolic forms by means of which men communicate, perpetuate, and develop their knowledge about and attitudes towards life."49 Similarly, in "Thick Description," the celebrated opening essay of his collection, he not only described "culture" as the concept "around which

Basic Assumptions of Boasian Anthropology," in The Shaping of American Anthropology, 1883-1911: A Franz Boas Reader, by Franz Boas (New York: Basic Books, 1974), 17.

46 Silverman, "The United States," 345.

47 Franz Boas, "Introduction," in Patterns of Culture, by Ruth Benedict (Boston: Houghton Mifflin, 1934), xv.

48 Silverman, "The United States," 287.

49 Clifford Geertz, "Religion As a Cultural System," in The Interpretation of Cultures: Selected Essays (New York: Basic Books, 1973), 89. 
the whole discipline of anthropology arose,"50 but he also gave it a particularistic, one might even say nationalistic, valence. He argued that according to his anthropological method, "descriptions of Berber, Jewish, or French culture must be cast in terms of the constructions we imagine Berbers, Jews, or Frenchmen to place upon what they live through, the formulae they use to define what happens to them.".51

As for de Martino, he not only understood that cultural relativism was "born out of the crisis of historicism in the first half of the twentieth century in Germany, constituting thus a typically Western phenomenon,"52 but also recognized the long shadow of the fascination with alterity within the rising cultural-discursive paradigm. In The End of the World, reviving terminology that originated in the context of crisis and nostalgia for cultural rebirth during the interwar years, de Martino described the apocalyptic 196os as an age marked by a state of "being-acted-upon" (essere-agito-da), "radical unfamiliarity," a sense of "strangeness (estraneità), Unheimlichkeit, and the Ganz Andere. ${ }^{53}$ American anthropology and its celebration of the contingent, the incommensurable, the different, and the unique is ultimately a return to the earlier historicism debate. ${ }^{54}$ In short, the crisis of 1965 was in many ways just another permutation of the crisis of 1918.

More recently, international scholarship has confirmed de Martino's intuitions, noting that Geertz inherited important characteristics from the German conception of culture as it rose in the American context under Franz Boas. Kate Crehan, for example, emphasized that for him too, "culture, like a nationality, tended [...] to be seen as referring to a specific people, often associated with a specific territory, and who were characterized by a particular world view, expressed through a common language. ${ }^{55}$ Similarly, Daniel Pals notes that "interpretive anthropology [...] appreciates the particular self-defining character of every culture." ${ }^{6}$ Finally, Silverman argues that Geertz's vision "pointed

50 Clifford Geertz, "Thick Description: Toward and Interpretive Theory of Culture," in The Interpretation of Cultures: Selected Essays (New York: Basic Books, 1973), 4.

$5^{1}$ Geertz, 15 .

$5^{2}$ De Martino, La fine del mondo, 281.

53 De Martino, 16.

54 Wolfgang Kämmerer, Friedrich Meinecke und das Problem des Historismus (Frankfurt am Main: Peter Lang, 2014), 296-99.

55 Crehan, Gramsci, Culture and Anthropology, 46. Crehan also used the example of James Clifford, another figure on Ferrari's list, to illustrate that "hybridity" is still underpinned by a "persistent assumption of the existence of distinct cultures, elements of which may intermingle in all kinds of ways but which nonetheless somehow remain rooted in that culture to which they "belong." Crehan, 61.

56 Daniel L. Pals, Eight Theories of Religion (New York: Oxford University Press, 2006), 308. 
to a highly particularistic, relativistic, and aesthetic program for anthropology, one that had much in common with earlier scholars' interest in ethos and was reminiscent of Benedict's notion of the patterning of distinctive, coherent cultural systems." 57

By recalling Otto's "wholly other" in his analysis, de Martino also suggested that the cultural-discursive paradigm's relativism was closely associated to another core trait of the insider-phenomenological approach, namely the nostalgic longing for a traditional and non-modern world-view. Just like relativism, this religious nostalgia likely stems from the Boasian conception of Kultur, whose origins reach well beyond the beginning of the twentieth century. In fact, the particularistic model of culture has its richest roots in German Romanticism, and, more specifically, in the thought of Johann Gottlieb Herder $\left(1744^{-1803)}\right)^{58}$ Opposing the Enlightenment belief in a teleological development of human civilization, Herder asserted the importance of a plurality of individual cultures. ${ }^{59}$ Boas himself, acknowledged the influence of Herder on his own thinking and argued in favor of "the diversity of cultures." In fact, following in the footsteps of the German romantic tradition, he proposed "a stance of cultural relativism, the idea that it is necessary to grasp cultures in their own terms and their own historical contexts before attempting generalizations." 60 Importantly, the relativists' insistence on the autonomy of cultures and the rejection of evolution was frequently accompanied by a reverse form of ethnocentrism, which celebrated the non-modern or "primitive" cultures as purer and more authentic expressions of Kultur. The principle of the peculiarity of culture, its particularistic richness, led to an infatuation with what is alien and a critique of what is one's own. As Helen Carr put it in her Inventing the American Primitive, "the Boasian ethnographers, like primitivist poets, created through their writing a world which possesses the virtues lost by modernity."61

De Martino, always attuned to the risk of division in times of crisis, described the final years of his life as a period in which the Western world had to make a choice that it already faced in the earlier half of the twentieth

57 Silverman, "The United States," 288.

$5^{8}$ Thomas Hylland Eriksen and Finn Sivert Nielsen, A History of Anthropology (London: Pluto, 2001), 23; William Yewdale Adams, The Philosophical Roots of Anthropology (Stanford: CSLI Publications, 2001), 313.

59 Consider, for example, Herder's Ideas on the Philosophy of the History of Mankind (1984-91).

6o Silverman, "The United States," 262.

61 Helen Carr, Inventing the American Primitive: Politics, Gender and the Representation of Native American Literary Traditions, 1789-1936 (New York: New York University Press, 1996), 252. 
century. Either, "one maintains faith in reason, as telos of humanity represented in distinguished fashion in the West, or one instead abdicates in front of the irrational and return to make it into the fundamental theme of life: This is the alternative called Europe, because we Europeans are living it in such a dramatic manner that has no equal in no other civilization of our planet." 62 As his description of Western or European exceptionalism already reveals, de Martino's choice was clearly on the opposite side of the spectrum from that of relativist anthropology.

In important ways, the interpretative approach to culture as it was practiced by Clifford Geertz is based on a revisitation of the Methodenstreit that ravaged the academy in the early twentieth-century. If the explanatory models of Marxism and structuralism started to gain dominance in the years after the Second World War, from the 1970s onward, anthropology took a turn towards hermeneutics. As one commentator put it, "it seemed fairer to understand (verstehen) the other than to explain (erklären) it." ${ }^{\prime 3}$ Lawson and McCauley have pointed to the fact that "those cultural anthropologists who have abandoned explanatory theorizing in favor of hermeneutic explorations" became important allies of the proponents of the insider-phenomenological approach, who "jumped at the chance to enlist hermeneutically aligned cultural anthropologists. They are grateful for allies with a 'humanistic' rather than a 'theological' or 'scientific' orientation." ${ }^{4}$ Geertz's work itself gives ample evidence of this attitude. In an interview from 2002, for example, he spoke of his analysis of the Balinese cockfight as follows: "You try to make sense of it, i.e., make sense that they make of it. Try to understand how they make sense of their world. In that way, it is phenomenological and hermeneutic. It is an attempt to understand things from the native's point of view."65

Both insider-phenomenological and cultural-discursive approaches value the stance of the religious practitioner more than the thinkers of the outsiderexplanatory approach. Gavin Flood, in his description of the third approach in religious studies, admits that "the idea of 'empathy' is relevant here," while immediately commenting on the "problematic" nature of this term as it "has

\footnotetext{
62 De Martino, "Promesse e minacce dell'etnologia," 106-7.

63 Werner Schiffauer, "Grenzen des ethnologischen Verstehens," in Grenzen des Verstehens: philosophische und humanwissenschaftliche Perspektiven, ed. Gudrun Kühne-Bertram and Gunter Scholtz (Göttingen: Vandenhoeck \& Ruprecht, 2002), 237.

64 E. Thomas Lawson and Robert N. McCauley, "Crisis of Conscience, Riddle of Identity: Making Space for a Cognitive Approach to Religious Phenomena," Journal of the American Academy of Religion 61, no. 2 (1993): 213.

65 Arun Micheelsen and Clifford Geertz, "I Don't Do Systems': An Interview with Clifford Geertz," Method \& Theory in the Study of Religion 14, no. 1 (2002): 10.
} 
unnecessary implications of a philosophy of consciousness which a dialogical model would wish to avoid."66 Of course, part of Flood's embarrassment stems precisely from the fact that the emphasis on states of consciousness and experience is pervasive throughout the cultural-discursive paradigm. Let us consider another example from Geertz's work, namely his definition of religion as "a system of symbols which acts to establish powerful, pervasive, and long-lasting moods and motivations in men." ${ }^{67}$ Unlike the objectivity of evolutionary or structuralist approaches, Geertz emphasized the primacy of subjective and intuitive experiences for apprehending religion. Georg Iggers, the historian of European intellectual history, noted that the Geertzian separation of the social reality from the web of symbolic significance ultimately "results in methodological irrationalism," as "the interpretation of symbols cannot be tested empirically." Even more importantly, Geertz's emphasis on culture as a web of meaningful symbols invited "the reintroduction of the anthropologist's subjectivity or imagination into his subject matter." ${ }^{\prime 6}$ Since the individual historical facts do not refer to an underlying reality, they need to be reconstituted in a meaningful way through the subjective imagination of the "interpretative" anthropologist. This form of cognitive relativism, of course, is just as inherent in any approach that explores religion through insider experience as it is for those who argue for a hermeneutical conception of culture as a text. Texts, by their very nature, can be read in innumerable ways. As Burke put it: "A fundamental problem with the metaphor of reading is that it seems to license intuition. Who is in a position to arbitrate when two intuitive readers disagree? Is it possible to formulate rules of reading, or at least to identify misreadings?"69

\section{Science Is Not for the Stateless: An Anticipatory Critique of the} Cultural Turn Based on the Ethnocentric Imperative

Based on my discussion in the first few chapters, it is obvious that the young Ernesto already articulated a critique of relativist thinking in religious studies, primarily in response to Rudolf Otto and Mircea Eliade. In his "Code for a Historicist Anthropology," written during the second half of the 1930s, de Martino's self-reflexivity took on an aspect that decisively contradicts the

66 Flood, Beyond Phenomenology, 148.

67 Geertz, "Religion As a Cultural System," 9o. Emphasis is mine.

68 Iggers, Historiography in the Twentieth Century, 125.

69 Peter Burke, What Is Cultural History? (Cambridge: Polity, 2004), 116. 
anthropology of guilt and self-critique found in relativism. Instead, the document culminates in a fierce defense of ethnocentrism: "Anthropology cannot be not Eurocentric." "That means," so de Martino continued, "it cannot be accompanied by the awareness that the Western civilization, maturing through Christianity, the reformation, the Enlightenment, and historicism, represents the highest level that humankind has successfully reached to this day."70 In light of these youthfully brash words, Fabrizio Ferrari argues that de Martino was "misguided by the then totalitarian climate in Italy," thus falling "prey to Eurocentrism and Christian-centrism." Not only that, he also concludes that "such a discourse, imbued with the 'rational modernity' and racial prejudice of fascism, will be eventually reconsidered and surpassed, especially in the Southern trilogy."71

Upon closer analysis, however, this assessment is problematic as de Martino's thinking was, until the end of his life, marked by "unconditional confidence in European culture."72 In an article dedicated to the folklore of Southern Italy, written in 1950, he brandished relativism as "philosophy of idiots (filosofia degl'imbecilli)" and explained that it was driven by the idea that "Western man should indeed get rid (spogliarsi) of his cultural heritage (patrimonio culturale)." ${ }^{73}$ In the notes to The End of the World, he similarly concluded that as the relativist "ethnographer attempts to totally disregard his own proper cultural history under the pretense of "making himself naked as a worm," he loses his own "specialistic vocation," and "exposes himself [...] to the risk of immediate ethnocentric analysis." ${ }^{74}$ Put differently, while de Martino recognized the danger of cultural imperialism, he was clear on the fact that it is not remedied by cultural relativism or some sort of anti anti-relativism.

We cannot place our own civilization next to the others and consider them all as equal perspectives, to be chosen at par as evaluating points of view. This is not how cultural "provincialism" is defeated. We need to engage in a dialogue with the world but we need to truly know our own part, otherwise we risk to fall into an enormous chatter (pettegolezzo), into an ambiguous and dumb gossiping, into an opportunism (camaleontismo)

70 De Martino, Naturalismo e storicismo nell'etnologia, 228.

71 Fabrizio M. Ferrari, Ernesto De Martino on Religion, 110.

72 Lanternari, La mia alleanza con Ernesto de Martino e altri saggi post-demartiniani, 125.

73 Ernesto De Martino, "Ancora sulla Storia del Mondo Popolare Subalterno," in Antropologia culturale e questione meridionale: Ernesto de Martino e il dibattito sul mondo popolare subalterno negli anni 1948-1955, ed. Carla Pasquinelli (Firenze: La Nuova Italia, 1977), 91-92. 
that simulates openness and variety of interests while being only a mask for a limitless abdication. ${ }^{75}$

In "Promises and Dangers of Anthropology," an influential article published in Fury, Symbol, Value (1962), de Martino argued that cultural relativism makes us apprehend the ethnographic encounter as an opportunity to abandon our own culture to immerse ourselves so much in the other that we completely lose our own values. Of course, de Martino himself was not entirely immune to the "dangers" involved in this type of thinking. Anthropology, so he concluded, is intended to "generate a cultural awareness, which, in the very moment it opened itself up to the intuition of so-called primitive societies, also put into question the bourgeois determination of Western civilization by opening it up to scrutiny and measuring its internal limits of origin and development." However, the goal of "putting ourselves into question," so he insisted, is not to abandon our own cultural values, but rather to strengthen our identity by means of a renewed sense of "Westernness."

All of this serves the intention to gain a greater loyalty to the character and destiny of Western civilization. [Its objective is] to avoid a false historical piety of the variously abdicating irrationalism, of the bewilderments of a relativism without perspective, and of the pseudo-objective suspensions of a neutralism that revealed the death of any capacity of choice and of the very will of history. ${ }^{76}$

Approvingly citing a passage of Tristes Tropiques, de Martino was also aware that he shared certain priorities with Lévi-Strauss as he too recognized that the confrontation with cultural alterity must invariably lead to self-reflection. In Structural Anthropology, for example, the French anthropologist described his endeavor in almost demartinoan terms, as characterized by "two apparently contradictory attitudes, namely, respect for societies very different from ours, and active participation in the transformation of our own society."77 At the same time, however, de Martino would have argued that while the Frenchman's work stood for the dangers of anthropology, his own position exemplified its promises. Placido Cherchi takes the view that "contrary to what it might seem, the growing attention that de Martino would dedicate to the theme of critical ethnocentrism [...] is not to be read as the consequence of an unconditional

75 De Martino, 281.

76 De Martino, "Promesse e minacce dell'etnologia," 87.

77 Lévi-Strauss, Structural Anthropology, 335. 
consensus to the perspective set down in the book of Lévi-Strauss, but as a need to exorcise its intimate riskiness." ${ }^{78}$ An exemplum for why this assessment might very well hold true comes from Race and History (1952), where Lévi-Strauss argued that relativism stands for a leveling off of societies as all cultures are seen to be equally worthy. In this publication, part of a UNESCO series against racism, the French anthropologist harshly criticized the "false evolutionism," which manifests as "a great temptation to try to arrange cultures in the first category in an order representing a succession in time."79 Instead, he suggested that all cultures should be seen on equal footing on a temporal horizon and be set apart in space.

De Martino could not possibly agree with the final consequences of this type of self-reflection as he feared that it would lead to an abdication of all the cultural values of the Western world. Many years after de Martino's death, scholarship on the French structuralist's work has confirmed that Lévi-Strauss himself had an important nostalgic streak. It was particularly Jean-Jacques Rousseau, who, for Lévi-Strauss, fulfilled this role of "a second strand or current in his thought." ${ }^{80}$ In fact, Lévi-Strauss himself acknowledges as much when he states that "Marx and Freud make me think," whereas "Rousseau sets me aflame." 81 The French anthropologist himself was exposed to importantalbeit frequently underestimated-influences from German speaking lands. More relevantly, perhaps, these German inspirations came to him indirectly through American anthropology. In fact, before being appointed as maitre de recherche at the Centre National de la Recherche Scientifique (CNRS) in 1948 and being elected to the Collège de France in 1959, Lévi-Strauss spent several years in the 1940s in exile in the United States, where he not only met Roman Jakobson at the New School for Social Research in New York, but also the anthropologist Alfred L. Kroeber. It is through these encounters in New York, which included visits to Franz Boas' ethnographic collections-displayed in the American Museum of Natural History — that Lévi-Strauss got imbued with a German tradition of culture.

Returning to the concluding remarks of de Martino's "Promises and Dangers," we find clues to just how radically his position differed from that of his French counterpart. Here, he articulated his conception of the defining characteristic of the ethnos of Western culture as the idea of a goal or end,

\footnotetext{
78 Cherchi, Il peso dell'ombra, 47.

79 Claude Lévi-Strauss, Race and History (Paris: Unesco, 1952), 16.

8o Tremlett, Lévi-Strauss on Religion, 23.

81 Claude Lévi-Strauss and Didier Eribon, Conversations with Claude Lévi-Strauss (Chicago: University of Chicago Press, 1991), 168.
} 
a telos. "The initial scandal of the ethnographic encounter," so de Martino argued, forces the anthropologist not only to "suspend and put into question" his own culture, but also allows him "to retrace [its history] with his thought and to newly found the telos of the West stimulated by the relationship with the ethnos." Thus, the "highest promise of a reformed anthropology" lies precisely in this renewed sense of selfhood in light of the scandal of encounter. ${ }^{82}$ In writing about anthropology, de Martino did not leave his science in the state of disintegration, rather the deconstruction advocated for by his insistence on self-reflexivity leads to a renewed energy and courage for construction. Put differently, relativism was never expressed in purely negative or deconstructive terms but rather in terms of combat and struggle to promote progress. De Martino's critical ethnocentrism, to use the words of Silvia Mancini, is premised on a "strong cognitive model." 83 Consider, for instance, the following passage from the same article, where we read:

Certainly, a science of the ethnos understood in this way required necessarily a series of choices and compromises (compromissioni) [that stand] in radical opposition to the ideal of science as absolute neutrality. It required that we take sides (prendere partito). [...] In reality, the anthropologist that claims to approach the ethnos by excluding - for "scientific professionalism" and for "love for objectivity" — any methodic and explicit verification of the values of Western civilization, makes himself unconsciously into a prisoner [...] of all of his inherent folklore of political, religious, and philosophical clashes (cozzanti). [...] The truth is that, in general, science is not of the stateless (apolidi) and that, in particular, the science of the ethnos establishes itself as the deliberate putting into question (messa in causa) of one's own Western citizenship under the stimulus of the initial scandal of the ethnographic encounter. ${ }^{84}$

The political undertones of de Martino's critique of "stateless-ness" is hardly a coincidence. In fact, his decisive and courageous science was, since his youth, always accompanied by a call to political activism. In his typically dialectical style, he recognized that our belonging to a state is both conservatively limiting and innovatively freeing at the same time. Being loyal to our homeland means that we can never encounter the other free of our own presuppositions, on the one hand, and that every political action can be revolutionary in transforming

82 De Martino, "Promesse e minacce dell'etnologia," 116.

83 Mancini, "Postface," 452.

84 De Martino, "Promesse e minacce dell'etnologia," 91. 
our own state, on the other. In response to cultural-discursive abdications of rootedness, de Martino suggested that we embrace a radical "loyalty" (fedeltà) to our "own cultural world" (proprio mondo culturale) in light of the steady rise of interest in cultural and religious alterities. De Martino's response to the crisis, thus, was as clear in the 1950s and 6os as it was decades earlier during his time as a student at the University of Naples: "I would not say that Europe can not abandon reason and embrace systems of choices that are foreign to its telos, but I say that it certainly should not. It should not do so because the cultural choices are not arbitrary, exchangeable at will, but form coherence and loyalty that also entail ultimate sacrifices. ${ }^{p 5}$

De Martino's awareness of relativism as a danger to his discipline grew stronger over time, with his judgment becoming more radical as the years passed. In The End of the World, de Martino responded to the nostalgia for alterity by introducing the idea of a "cultural homeland" (patria culturale). It is only through the appaesamento - a term that can be translated as "assimilation," "territorialisation" or "appropriation" - within one's own cultural horizon that humanity can function. In emphasizing the importance of one's own homeland, de Martino's position must be distinguished not only from that of Lévi-Strauss, but also from that of the cultural-discursive paradigm. In "Thick Description: Toward and Interpretive Theory of Culture," Geertz wrote that "cultural analysis is (or should be), guessing at meaning, assessing the guesses, and drawing explanatory conclusions from the better guesses, not discovering the Continent of Meaning and mapping out its bodiless landscape." 86 If Geertz concluded his relativist manifesto by sarcastically stating that "if we wanted home truths, we should have stayed at home," ${ }^{87}$ de Martino invited anthropologists to do just that: "European civilization is an asset to defend, increase (accrescere), and expand (dilatare)." ${ }^{88}$ In Magic and Civilization, de Martino discussed the positive aspects of one of the most ethnocentric elements of Western culture, namely the "anti-magical polemic."

$[\ldots]$ in the West, the concept of magic also has weight as a protective measure against this different sickness, which is the radical unfaithfulness (infedeltà) to the anti-magical polemic of our civilization; with the abdication in front of the charismas of magic as consequence. Every

\footnotetext{
85 De Martino, 106-7.

86 Geertz, "Thick Description: Toward and Interpretive Theory of Culture," 20.

87 Clifford Geertz, "Distinguished Lecture: Anti Anti-Relativism," American Anthropologist 86, no. 2 (1984): 276.

88 De Martino, La fine del mondo, 281.
} 
civilization chooses its own "loyalty" (fedeltà) and ours has chosen the loyalty to reason and history. In virtue of this choice, when the reason we possess appears too narrow in front of new problems of life and history, we are compelled to consciously choose a broader and more human reason. We should never disavow the type of loyalty in which we are culturally and historically inserted. Our civilization has chosen loyalty to reason and history: not in the dogmatic sense of a choice which took place once and for all in a given era, but in the sense of a choice, which is always called into questioned anew, tried and re-tried, modified and corrected, or even reinterpreted in new light as the particular historical situations gradually change. ${ }^{89}$

This dialectical conception of loyalty as something that is not a dogmatic choice that has been taken once and for all, but rather a continuous commitment to choose in light of changing circumstances ultimately culminates in the "ethos of transcendence," which de Martino developed in the final years and months of his life.

89 De Martino, Magia e civiltà, 9-10. 